\title{
AGRICULTURAL LAND ON BUILT-UP HOUSING LOTS AND THE INCOMES OF COMMUNES: AN EXAMPLE OF ROKIETNICA COMMUNE IN THE POZNAŃ AGGLOMERATION
}

\author{
Barbara MaĆKIEWicz ${ }^{1}$, Cecylia Karalus-Wiatr ${ }^{2}$ \\ ${ }^{1}$ Institute of Socio-Economic Geography and Spatial Management, Adam Mickiewicz University in Poznań, \\ Poland \\ ${ }^{2}$ Poviat Centre of Geodetic and Cartographic Documentation in Poznań, Poland
}

Manuscript received: January 16, 2017

Revised version: May 8, 2017

\begin{abstract}
MaćKiewicz B., Karalus-Wiatr C., 2017. Agricultural land on built-up housing lots and the incomes of communes: An example of Rokietnica commune in the Poznań agglomeration. Quaestiones Geographicae 36(2), Bogucki Wydawnictwo Naukowe, Poznań, pp. 95-106, 4 tables, 6 figs.

AвSTRACT: The strong connection between urbanisation processes and the transformation of farmland into built-up areas - mostly residential - has already been tackled in the literature. Still, in Poland this process of farmland loss, generally thought to be irreversible, occurs in a specific, often irrational and not fully registered way. What is more, this development is favoured by legislation, especially rules controlling the exclusion of land from agricultural production and real-estate taxation. Among the many detrimental consequences of those regulations are incomes of communes lower than they should be. The problem tackled in the article is that of the exclusion from agricultural use of only fragments of geodetic lots on which building investments are going on. The cost of the exclusion and the difference in the rates of the agricultural tax and the real-estate tax very often result in the exclusion of only a part of a lot, while the rest of it is formally still in agricultural use, even though its owner does not conduct any agricultural activity there. In this case two taxes have to be paid from one lot: the real-estate tax, on the land taken out of agricultural use and the building erected on it, and another, the agricultural tax, on land that is still a piece of farmland. This situation, especially in areas undergoing rapid urban sprawl, is common in Poland and has unfavourable consequences for the incomes of communes. It also leads to a discrepancy between data from the real-estate cadastre and the actual area of land in agricultural use, which greatly hampers an exact measurement and control of the real losses of land performing the agricultural function, including that with high-quality soils. The conducted research demonstrated that in 2014 nearly $7 \%$ (927) of all geodetic lots in Rokietnica commune, situated in the immediate neighbourhood of Poznan, were builtup housing lots, mostly carrying detached single-family houses, with fragments of farmland. Almost a half $(49.4 \%)$ of the total area of those lots, $42 \mathrm{ha}$, was still agricultural land in the real-estate cadastre and subject to taxation not by the real-estate tax, but the much lower agricultural tax. Because of this difference in the two taxes, the annual receipts of the commune budget are 186,601 zlotys (43,395 euro) lower. It also turned out that more than $50 \%$ of farmland on those lots (21.8 ha) was arable land of the good land-capability class III, which is high for the conditions in the Poznan agglomeration. This not only corroborates the findings of earlier studies highlighting significant losses of good-quality arable land taking place as a result of urban sprawl, but it also means that in the Polish conditions actual losses are much higher than would follow from records in the real-estate cadastre. It can also be stated that the Polish legal rules not only fail to adequately protect farmland situated within metropolitan areas, but even favour its excessive loss.
\end{abstract}

KEY WORDS: exclusion of land from agricultural production, farmland conversion, incomes of communes, real-estate tax, agricultural tax, urban sprawl, decrease of agricultural land 


\section{Introduction}

The strong connection between the processes of urban sprawl and the transformation of farmland into built-up, mostly residential, areas has already been tackled in the literature (cf. Levia, Page 2000; Heimrich, Anderson 2001; Polimeni 2005; Satterthwaite et al. 2010; Pribadi, Pauleit 2015; Skog, Steinnes 2016). It has also been found that, for historical reasons, the sprawl often affects the most fertile soils because best-quality farmland lies close to urban areas (Scalanghe, Marsan 2009; Satterthwaite et al. 2010; Salvati 2013), and urban sprawl is thought to be the main driver of its conversion. Undoubtedly, agricultural land is negatively affected by population growth and urbanisation processes, and urban sprawl has serious consequences for the conversion of farmland (Thórth 2012; Martellozzo et al. 2014; Skog, Steinnes 2016). It is also believed that continuous urbanisation leading to a further transformation of farmland into built-up areas may soon affect food security at a global scale (FAO and ITPS 2015; Gardi et al. 2015). Therefore many authors, e.g. Skog and Steinnes (2016), stress that urgently needed are further and more detailed studies of the effect of urban sprawl on the fast advancing loss of farmland. They also emphasise that in this situation it would be highly justified, even necessary, to attach proper weight to the scale of this problem, and they recommend introducing concrete farmland protection policies as soon as possible. They observe that "land use planning and policies must demonstrate how we can change the consumption of farmland by containing urban growth" (Skog, Steinnes 2016: 195). However, in Poland this problem still seems to be given scarce attention, if not downplayed altogether. For many years the process of farmland loss has occurred in a specific, often irrational and not fully registered way. What is more, it has been favoured by legislation, especially rules controlling the exclusion of land from agricultural production and real-estate taxation. Among the many detrimental consequences of those regulations are also incomes of communes lower than they should be (Maćkiewicz, Motek 2014). Since the very start of the systemic transformation in Poland one can observe a steady decline in the area of farmland. This is chiefly the result of taking it out of agricultural production with investment purposes in mind, the predominant purpose being its transformation into a housing area (cf. Kacprzak, Maćkiewicz 2011, 2013; Maćkiewicz, Kacprzak 2015; Kacprzak, Kołodziejczak 2016). The most dynamic changes of farmland into building land occur as a result of urban sprawl in rural areas lying in close vicinity of large urban centres. For years there has been an expansion of dispersed settlement into rural areas there (cf. Bański 2005; Kacprzak, Staszewska 2009, 2011; Kajdanek 2012; Lisowski 2007; Maćkiewicz 2007, 2011; Wójcik 2008; Śleszyński 2014, 2015; Maćkiewicz 2016). But because of the cost of the exclusion of land from agricultural production and the difference in the rates of the agricultural tax and the real-estate tax, very often only a part of a lot is taken for investment purposes while the rest of it is formally still in agricultural use, even though its owner does not conduct any agricultural activity there (Maćkiewicz, Motek 2014). This article is the first in Poland to tackle, at the scale of an entire commune, the problem of the exclusion from agricultural production of only fragments of geodetic lots where building investments have been made. This has significant consequences for commune budgets. It also makes it very difficult to establish the actual area in agricultural use, and hence to assess actual losses in the area of farmland. The goal of this paper is to examine the effect of the fragmentary transformation of farmland into housing lots on the receipts of communes from the real-estate tax.

\section{Receipts of communes: the real-estate tax and the agricultural tax}

Local taxes are among the most important sources of income of self-government units in Poland. Apart from their basic role, i.e. providing budgetary means for public tasks (a fiscal function), they also perform redistributive, stimulating and informational-controlling functions (for more details, see e.g. Gaudemet, Molinier 2000; Malinowska-Misiąg, Misiąg 2014; Owsiak 2016). Of special significance among local taxes are the real-estate tax and the agricultural tax, which belong to the group of so-called land taxes. They also belong to property taxes, i.e. those a significant feature of which is that they arise from 
the very fact of possessing a property, whether or not it brings any profit. The real-estate tax is regulated by the Taxes and Local Duties Act of 12 January 1991 (Official Gazette of 2016, position 716, with later changes), and the agricultural tax, by the Agricultural Tax Act of 15 November 1984 (Official Gazette of 2016, position 617, with later changes).

The subjects of the real-estate tax and the agricultural tax are natural persons, legal persons and organisational units with no legal personality that are primarily owners, independent possessors or perpetual users of a property (for more details on local taxes, see e.g. Etel et al. 2008; Miszczuk 2009; Borszowski 2011; Sygut 2014). The objects of the real-estate tax are land, buildings or their parts, and constructions or their parts connected with conducting an economic activity. In the case of the agricultural tax, this is land classified in the Land and Buildings Records as agricultural land or as land with tree or shrub clusters growing on agricultural land, with the exception of land occupied to conduct an economic activity other than farming. In the real-estate tax, the basis of taxation is the area of land, the usable floor area of buildings and their parts, and their value. In the agricultural tax, the basis of taxation for the land on farms is the number of conversion hectares (determined on the basis of the area, kind and class of agricultural land and the tax district), and for the remaining land - its area. The rates of the real-estate tax are established by the commune council in a vote, but the voted rates cannot exceed the values allowed by the Act. In turn, the rate of the agricultural tax depends on the mean purchase price of rye.

The real-estate tax is one of the most profitable local taxes in fiscal terms. In the years 2012-2015 it gave the budgets of communes and poviat-ranking towns more than 17 billion zlotys annually
(Table 1), which accounted for more than $10 \%$ of their total receipts. The role of the agricultural tax in financing local-government tasks is much smaller. In the study period this tax generated a mean annual income of about 1.5 billion zlotys, or $1 \%$ of all budgetary revenues.

From a fiscal point of view and that of the maximisation of commune revenues, a favourable situation is one when most land in a commune comes under the real-estate tax, and not the agricultural tax. The rules of putting farmland to non-agricultural uses and the exclusion of land from agricultural production are determined primarily by the Farmland and Woodland Protection Act of 3 February 1995 (Official Gazette of 2015, position 716 , with later changes). The basic rule written in the Act is that the land allowed to be used for non-agricultural purposes is primarily that described in land records as wasteland, and if there is no wasteland, other land with the lowest productive value. A change of farmland into land used for non-agricultural purposes takes place in a local physical development plan. In accordance with the Physical Planning and Spatial Development Act (Official Gazette of 2015, position 778 , with later changes), before a commune council is given a local plan to pass, the head or president of a town brings forward a motion for changing farmland into non-agricultural land. In the case of agricultural land of classes I-III, such a consent is given by the minister competent in rural development matters, after the Agricultural Chamber has expressed its opinion. The consent itself does not change the purpose of the land; it is necessary for the decision to appear in a local physical development plan. However, this procedure does not concern land situated within the administrative limits of towns, because according to article 10a of the Farmland and Woodland Protection Act, the rules concerning

Table 1. Receipts of communes and poviat-ranking towns from the real-estate tax and the agricultural tax in the years 2012-2015.

\begin{tabular}{|c|c|c|c|c|c|}
\hline \multirow{2}{*}{ Year } & \multirow{2}{*}{ Total receipts in zlotys } & \multicolumn{2}{|c|}{ Real-estate tax } & \multicolumn{2}{|c|}{ Agricultural tax } \\
\cline { 3 - 6 } & & Income in zlotys & $\begin{array}{c}\text { Proportion of to- } \\
\text { tal receipts in \% }\end{array}$ & Income in zlotys & $\begin{array}{c}\text { Proportion of total receipts } \\
\text { in } \%\end{array}$ \\
\hline 2012 & $139,654,496,424$ & $17,602,654,355$ & 12.6 & $1,545,893,812$ & 1.1 \\
\hline 2013 & $144,260,001,155$ & $18,729,408,917$ & 13.0 & $1,665,241,291$ & 1.2 \\
\hline 2014 & $194,337,188,058$ & $19,532,020,159$ & 10.1 & $1,653,534,863$ & 0.9 \\
\hline 2015 & $199,018,948,994$ & $20,171,305,299$ & 10.1 & $1,592,972,997$ & 0.8 \\
\hline
\end{tabular}

Source: own compilation on the basis of budgetary reports of local government units in the years 2012-2015, Ministry of Finance. 
the conversion of farmland into non-agricultural land do not apply to it (cf. Kwartnik-Pruc et al. 2011; Bielecka, Całka 2011; Maćkiewicz, Motek 2014). It should be kept in mind, however, that an actual change in the function of agricultural land, i.e. in its use and classification in the real-estate cadastre, takes place not on the basis of a change in its use in a local physical development plan, but via the procedure of excluding it from agricultural production. The exclusion of agricultural land formed from soils of mineral and organic origin, put into classes I, II, III, IIIa and IIIb, as well as classes IV, IVa, IVb, V and VI formed from soils of organic origin, takes place via a decision of the head of a poviat council. This decision has significant consequences for commune budgets because the tax paid for an area excluded from agricultural production is the real-estate tax rather than the agricultural tax. Higher rates of the real-estate tax translate into higher budgetary receipts. On the other hand, however, there is an increase in taxes for people who have applied to exclude their land from agricultural production. It should be emphasised that in the light of the law in force in Poland, it is not obligatory to give up agricultural production in the total area of a building lot. As a result, applications for exclusion usually do not concern entire lots, but only the parts with buildings. The other parts are not excluded from agricultural production, even though the owner does not conduct any farming on it (Fig. 1). This situation causes two taxes to be levied on a single lot: the real-estate one, on the building and the agricultural land taken out of production, and another, the agricultural tax, on land that has remained farmland.

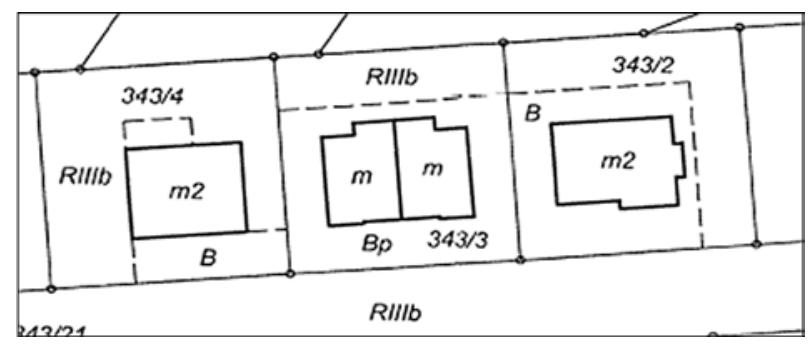

Fig. 1. Agricultural land on built-up housing lots - an example.

B - building and part of lot covered by real-estate tax, R $\mathrm{IIIb}$ - part of lot remaining to be farmland and coming under agricultural tax.

Source: Land and Buildings Records, Poviat Centre of Geodetic and Cartographic Documentation in Poznań.
The procedure involving the exclusion from agricultural use of only a part of a lot assigned in a local physical development plan for other purposes, e.g. single-family housing, is facilitated by the Farmland and Woodland Protection Act of 3 February 1995 (Official Gazette of 2015, position 909, with later changes). In accordance with its provisions, the exclusion of up to $500 \mathrm{~m}^{2}$ of farmland from agricultural production in order to build a single-family house there is exempt from all financial duties, i.e. from the payment of public dues and annual charges (Kwartnik-Pruc et al., 2011; Bielecka, Całka 2012; Kwartnik-Pruc et al. 2013; Maćkiewicz, Motek 2014). Since the Act does not require the exclusion of a lot as a whole, in order to minimise the costs investors take care for the area of farmland excluded from agricultural production not to exceed the limit set free of charge. In practice, this very often means that the fragment excluded from agricultural production only slightly exceeds the outline of buildings erected on the lot (Fig. 1). Such fragmentary exclusions of farmland on building lots has for years been a widely adopted practice in Poland, universal in areas undergoing rapid suburbanisation. Its effects must be assessed as detrimental. By reducing the cost of the exclusion of farmland from agricultural production it leads to its irrational management, including areas with high-quality soils; it also detracts from the budgetary revenues of communes and makes the real-estate cadastre inaccurate.

\section{Partial exclusion of land from agricultural production and receipts ofRokietnica commune}

\section{Study area, materials and methods}

The analyses conducted covered the entire rural commune of Rokietnica, which borders the city of Poznan on the north-west. It should be emphasised that in comparison with the other communes of Poznań poviat Rokietnica has good-quality soils; a substantial proportion of its area belongs to high land-capability classes (cf. Kacprzak, Maćkiewicz 2011; Maćkiewicz 2011; Maćkiewicz, Motek 2014; Maćkiewicz, Kacprzak 2015). Because of the immediate neighbourhood of Poznań, since the early 1990s Rokietnica 
commune has been undergoing a dynamic process of suburbanisation. In effect, many areas where farming used to be practised are now occupied by buildings, mostly detached single-family houses (cf. Maćkiewicz 2015, 2016; Mikuła 2016). It was possible to carry out all studies necessary for this article thanks to the acquisition and analysis of detailed data from the Land and Buildings Records of the Poviat Centre of Geodetic and Cartographic Documentation (the real-estate cadastre) in Poznań. The research was conducted in the system of geodetic lots, i.e. the smallest units of land division. On the basis of laborious and time-consuming analyses of the contents of cadastral maps and other cadastral information, all built-up housing lots were identified where partial exclusions of farmland from agricultural production could be found in December 2014; in other words, all lots with both, land classified in the real-estate cadastre as a built-up housing area and that described as agricultural land. The next step involved calculating, in the system of geodetic districts, the area of agricultural land left on built-up housing lots, taking into consideration also its quality, i.e. its land-capability class. This allowed an estimation of losses in the receipts of the commune resulting from the agricultural tax being paid for it rather than the decidedly higher real-estate tax. It also allowed establishing the scale of discrepancies between the records in the real-estate cadastre and the actual use of farmland being a part of the built-up housing lots. It also provided a basis for determining the scale of good-quality farmland lost for the agricultural function, i.e. of a high land-capability class occurring on building lots. Use was also made of the Spatial Information System of Rokietnica commune and the information supplied by its Economic Development Section and the Tax Service, Local Charges and Vindication Section. An important completion of the material collected was observations, information and comments obtained in the course of two in-depth expert interviews. One was conducted with the director of the Poviat Centre of Geodetic and Cartographic Documentation in Poznań. It mainly concerned problems involved in the recording of farmland and resulting from the exclusion from agricultural production of only a fragment of a building lot. The other was devoted to losses in the commune's receipts resulting from this exclusion and to the physical development of farmland situated in the agglomeration. The answers were given by the head of the Economic Development Section of Rokietnica commune.

\section{Agricultural land on built-up housing lots in Rokietnica commune}

The conducted analysis showed that at the close of 2014 nearly 7\% (927) of all geodetic lots (both built-up and building-free) in Rokietnica commune were built-up housing lots with fragments of agricultural land. This means that a part of each of those lots was classified in the real-estate cadastre as B, or a built-up housing area, while the rest kept its agricultural status (cf. Fig. 1). Almost in all cases this agricultural land was arable land, designated in the real-estate cadastre by the symbol R. Grassland ( $\mathrm{E}$ ) accounted for only a small proportion of it (Table 2).

It was established that built-up housing lots with agricultural land could be found in all the geodetic districts of Rokietnica commune (Table 3, Fig. 2). But their greatest number (322) was recorded in the centrally situated Rokietnica district, Kiekrz, which neighbours directly on Poznań (126), and Krzyszkowo (119). It is worth noting that those districts are the most urbanised areas in Rokietnica commune (Fig. 3). There was also a large number of such lots in the districts of Bytkowo, Mrowino and Rostworowo: 84, 83 and 73 , respectively. Their smallest number occurred in the districts of Dalekie (1), Starzyny (3) and Żydowo (3). In some districts the proportion of built-up housing lots with agricultural land was especially high. In Rostworowo, Krzyszkowo and Bytkowo they accounted for 15.3\%. 13.7\% and $11.7 \%$, respectively, of all geodetic lots in the district. This means that in those districts there was land classified as agricultural apart

Table 2. Types of land use on built-up housing lots in Rokietnica commune, 2014.

\begin{tabular}{|l|c|r|}
\hline \multicolumn{1}{|c|}{ Type of land use } & $\begin{array}{c}\text { Symbol of land use in } \\
\text { real-estate cadastre }\end{array}$ & $\begin{array}{c}\text { Area in } \\
\text { ha }\end{array}$ \\
\hline Housing areas & $\mathrm{B}$ & 43.0494 \\
\hline Arable land & $\mathrm{R}$ & 41.9533 \\
\hline Grassland & $€$ & 0.0267 \\
\hline Total & & 85.0294 \\
\hline
\end{tabular}

Source: own compilation on the basis of data from the Poviat Centre of Geodetic and Cartographic Documentation in Poznań. 
Table 3. Proportion of built-up housing lots with agricultural land in the total number of lots in Rokietnica commune, 2014.

\begin{tabular}{|l|r|r|c|}
\hline Geodetic district & $\begin{array}{c}\text { Total number } \\
\text { of lots }\end{array}$ & $\begin{array}{c}\text { Number of housing lots with agri- } \\
\text { cultural land }\end{array}$ & $\begin{array}{c}\text { Housing lots with agricultural land in total } \\
\text { number of lots in \% }\end{array}$ \\
\hline Bytkowo & 719 & 84 & 11.7 \\
\hline Cerekwica & 1,059 & 30 & 2.8 \\
\hline Dalekie & 105 & 1 & 1.0 \\
\hline Kiekrz & 2,518 & 126 & 5.0 \\
\hline Kobylniki & 863 & 21 & 2.4 \\
\hline Krzyszkowo & 868 & 119 & 13.7 \\
\hline Mrowino & 1,374 & 83 & 6.0 \\
\hline Napachanie & 626 & 13 & 2.1 \\
\hline Pawłowice & 264 & 7 & 2.7 \\
\hline Przybroda & 237 & 10 & 4.2 \\
\hline Rogierówko & 251 & 11 & 4.4 \\
\hline Rokietnica & 3,381 & 322 & 9.5 \\
\hline Rostworowo & 509 & 78 & 15.3 \\
\hline Sobota & 290 & 15 & 5.2 \\
\hline Starzyny & 152 & 3 & 2.0 \\
\hline Żydowo & 236 & 4 & 1.7 \\
\hline Total & 13,452 & 927 & 6.9 \\
\hline
\end{tabular}

Source: own compilation on the basis of data from the Poviat Centre of Geodetic and Cartographic Documentation in Poznań.

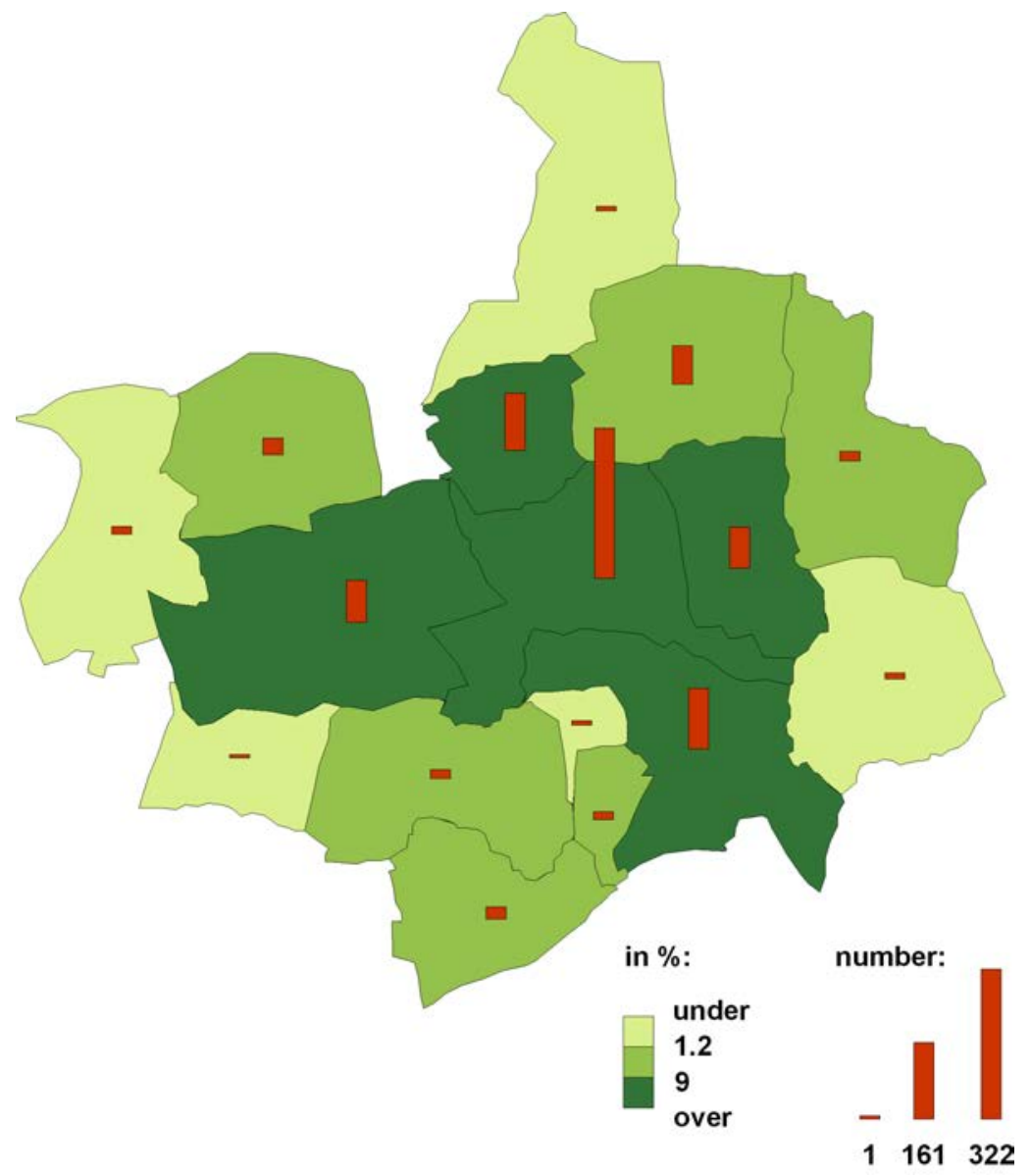

Fig. 2. Built-up housing lots with agricultural land, 2014 (Rokietnica commune in the system of geodetic districts). Source: own compilation on the basis of data from the Poviat Centre of Geodetic and Cartographic Documentation in Poznań. 


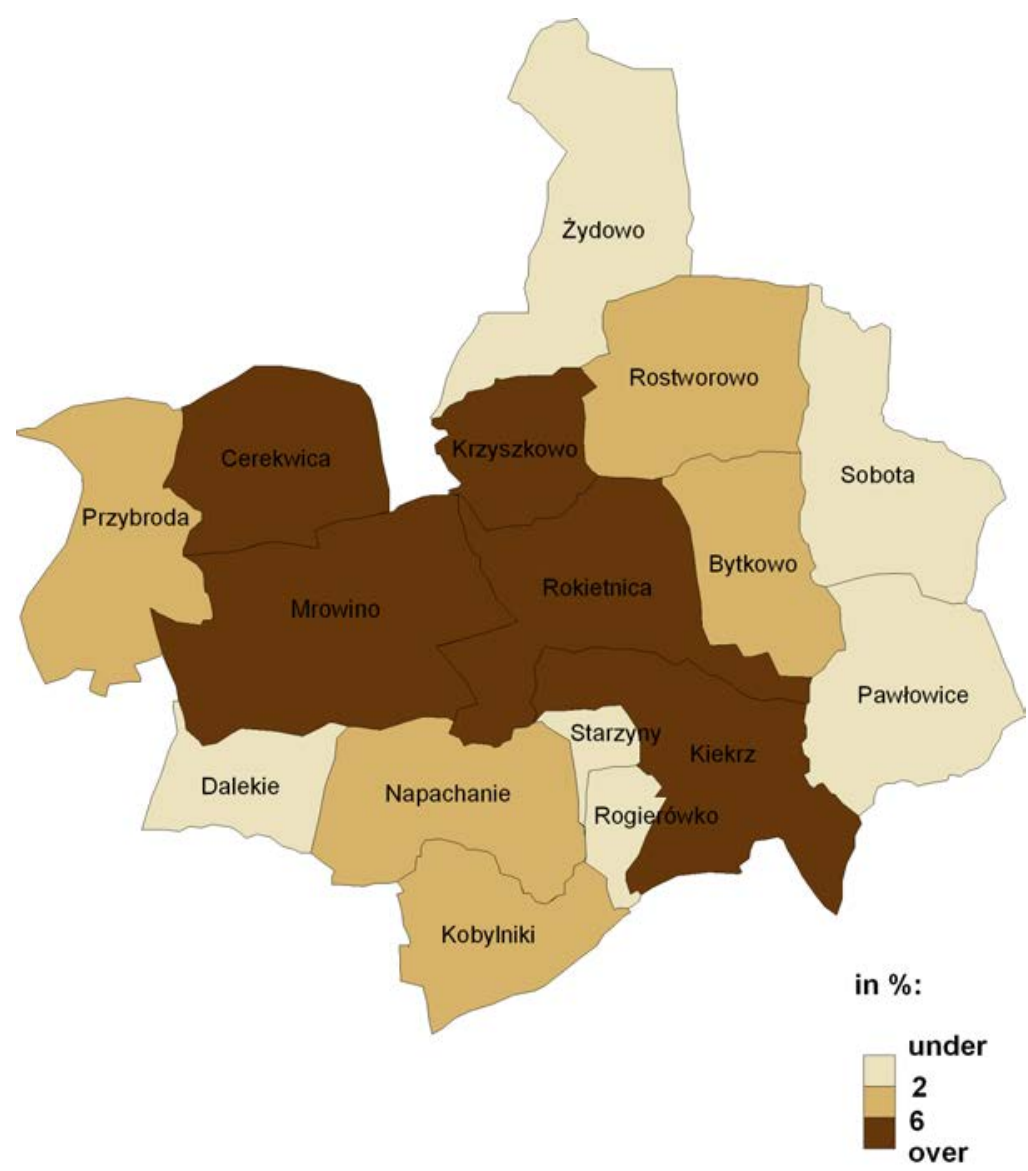

Fig. 3. Housing areas, 2014 (Rokietnica commune in the system of geodetic districts).

Source: own compilation on the basis of data from the Poviat Centre of Geodetic and Cartographic Documentation in Poznań.

from a built-up housing area on more than every ninth geodetic lot (Table 3). A high proportion of this type of lots $(9.5 \%)$ also characterised the Rokietnica district, where there was almost one built-up housing lot containing some agricultural land to each ten geodetic lots.

The research showed that more than a half of agricultural land (21.77 ha) on built-up housing lots was arable land of the good capability class III, high in the conditions of the Poznan agglomeration (Fig. 4). The next 35\% (14.63 ha) of agricultural land on those lots had soils of classes IVa and IVb, i.e. of medium quality, but quite good in the conditions of Poznan poviat. As to the quality of soils on agricultural land that is part of builtup housing lots, worth noting is the Rokietnica district. It is the most urbanised district in the commune. Built-up housing lots constitute nearly $32 \%$ of its area. Even so, there are 14.27 ha of arable land on built-up housing lots, of which more than a half -7.74 ha - are soils of class III (Table 4). This situation is understandable; it was unavoidable in the process of the physical development of Rokietnica commune. Soils of class III occur, for example, in the central part of the town of Rokietnica, i.e. in an area most predestined to be urbanised. Hence its convergence from farmland to housing and service areas was fully

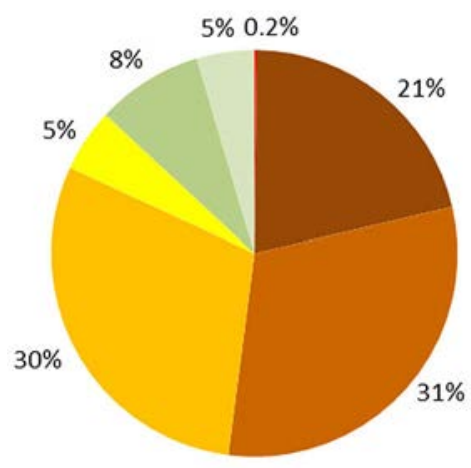

soil class:

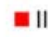

allla

a IIIb

$=\mathrm{IVa}$

$\mathrm{IVb}$

E

VI

Fig. 4. Quality of farmland on built-up housing lots in Rokietnica commune, 2014.

Source: own compilation on the basis of data from the Poviat Centre of Geodetic and Cartographic Documentation in Poznań. 
Table 4. Land-capability classes of farmland on built-up housing lots in Rokietnica commune, 2014.

\begin{tabular}{|l|c|c|c|c|c|c|c|c|}
\hline \multirow{2}{*}{ Geodetic district } & \multicolumn{7}{|c|}{ Land-capability class and area in ha } \\
\cline { 2 - 9 } & II & IIIa & IIIb & IVa & IVb & V & VI & Total \\
\hline Bytkowo & - & 0.4340 & 2.7992 & 0.6458 & - & 0.0267 & - & 3.9057 \\
\hline Cerekwica & - & 0.5308 & 0.0667 & 0.3731 & - & 0.1350 & 0.4064 & 1.5120 \\
\hline Dalekie & - & 0.0733 & - & - & - & - & - & 0.0733 \\
\hline Kiekrz & - & 0.1299 & 0.2494 & 2.6711 & 0.4599 & 1.1750 & 0.4897 & 5.1750 \\
\hline Kobylniki & - & - & 0.0583 & 0.3369 & 0.3226 & 0.1812 & 0.2689 & 1.1679 \\
\hline Krzyszkowo & - & 0.0116 & 3.9688 & 0.9101 & 0.2077 & 0.1150 & - & 5.2132 \\
\hline Mrowino & - & 0.7950 & 0.5348 & 0.4361 & 0.2182 & 0.8416 & 0.4574 & 3.2831 \\
\hline Napachanie & - & - & - & 0.2171 & 0.0495 & 0.3725 & - & 0.6391 \\
\hline Pawłowice & - & - & - & - & 0.0224 & 0.2999 & 0.1493 & 0.4716 \\
\hline Przybroda & - & 0.3409 & 0.0068 & 0.1394 & - & - & - & 0.4871 \\
\hline Rogierówko & - & - & 0.0422 & 0.2916 & - & 0.0762 & - & 0.4100 \\
\hline Rokietnica & - & 2.7044 & 5.0332 & 5.3727 & 0.8299 & 0.2629 & 0.0656 & 14.2687 \\
\hline Rostworowo & - & 3.0535 & 0.0352 & 0.9597 & - & 0.0786 & 0.0890 & 4.2160 \\
\hline Sobota & - & 0.6331 & 0.1014 & - & - & - & - & 0.7345 \\
\hline Starzyny & - & - & - & 0.1713 & - & - & - & 0.1713 \\
\hline Żydowo & 0.0800 & 0.1715 & - & - & - & - & - & 0.2515 \\
\hline Total & 0.0800 & 8.8780 & 12.8960 & 12.5249 & 2.1102 & 3.5646 & 1.9263 & 41.9800 \\
\hline
\end{tabular}

Source: own compilation on the basis of data from the Poviat Centre of Geodetic and Cartographic Documentation in Poznań.

justified. Still, at least some farmland located in the Rokietnica district with soils of the high class III could, and should, remain in agricultural use. This concerns areas distant from the town's centre, where the scattering of buildings makes the housing function unfavourable, if only because of the high cost of providing them with infrastructure. It should be realised, however, that the protection of this farmland against development, not always desirable and rational, was very hard and sometimes even impossible for the commune, because private non-farming persons who had bought it did all they could to erect buildings on them, e.g. using the rules in force concerning decisions about building conditions.

\section{Losses in the commune's budgetary receipts: the real-estate tax and the agricultural tax}

The conducted research showed that in Rokietnica commune there were almost 42 hectares of agricultural land on built-up housing lots. As a result, the commune's receipts from this entire area come from the agricultural tax, and not the decidedly higher real-estate tax. This is so because if there is a built-up housing area and agricultural land on a single lot, two taxes are levied on it: one, the real-estate tax on the building and the land excluded from agricultural production, and another, the agricultural tax, on land that has remained farmland. Given the rates of the real-estate tax and the agricultural tax currently in force in Rokietnica commune, i.e. 0.47 zlotys $/ \mathrm{m}^{2}$ on residential land and 0.0255 zlotys/ $\mathrm{m}^{2}$ on agricultural land that is not part of a farm, it is easy to calculate that owing to the difference in the rates of those two taxes, each year the commune's receipts are 186,601 zlotys (43,395 euro) lower. Agricultural land on built-up housing lots has the largest area in the districts of Rokietnica (14.27 ha), Krzyszkowo (5.21 ha) and Kiekrz (5.17 ha). The yearly losses resulting from the difference in the taxes amount to 63,424 zlotys $(14,750$ euro), 23,173 zlotys (5,389 euro) and 23,003 zlotys (5,349 euro), respectively (Fig. 5). These losses are also significant in the districts of Rostworowo (18,740 zlotys; 4,358 euro), Bytkowo (17,361 zlotys; 4,037 euro) and Mrowino (14,593 zlotys; 3,394 euro). In the other districts of Rokietnica commune the area of agricultural land on builtup housing lots is much smaller, and the differences resulting from their taxation by the agricultural tax rather than the real-estate tax amount to a few thousand zlotys.

It can be observed that the total area of builtup housing lots in Rokietnica commune - symbol B in the Land and Buildings Records - is 303 ha, while that of agricultural land on built-up 


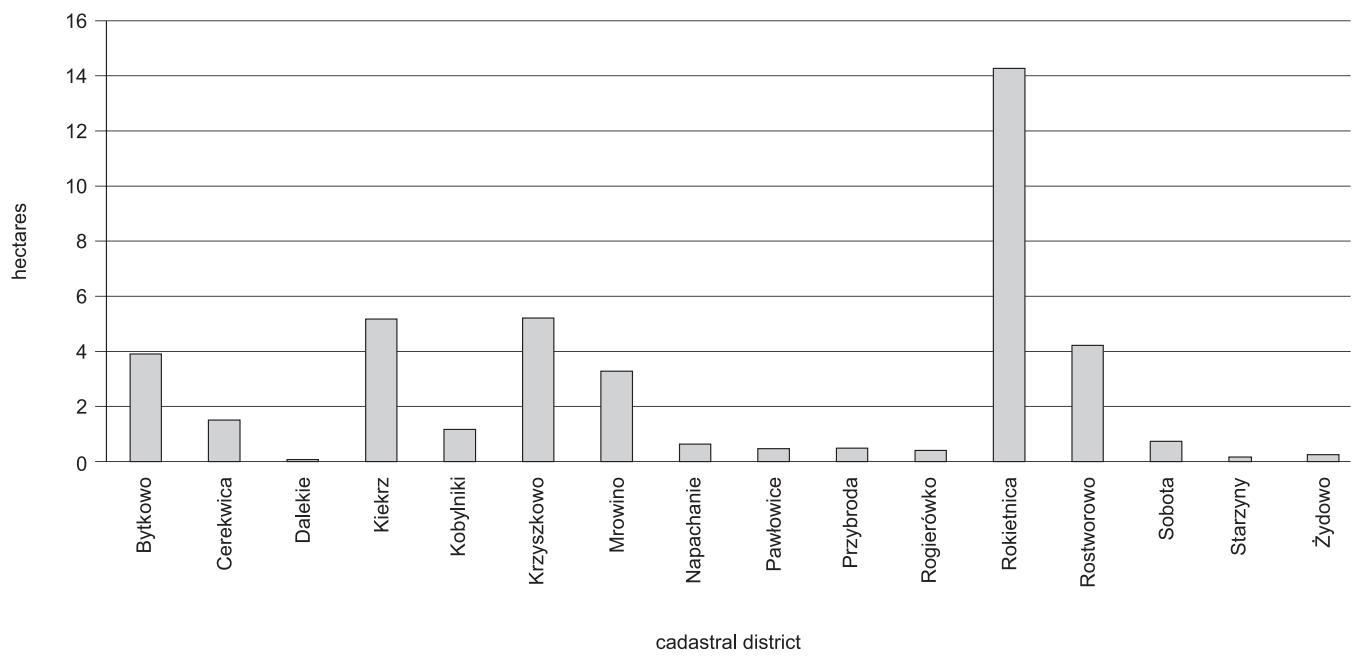

Fig. 5. Area of agricultural land on built-up housing lots in Rokietnica commune, 2014.

Source: own compilation on the basis of data from the Poviat Centre of Geodetic and Cartographic Documentation in Poznań.

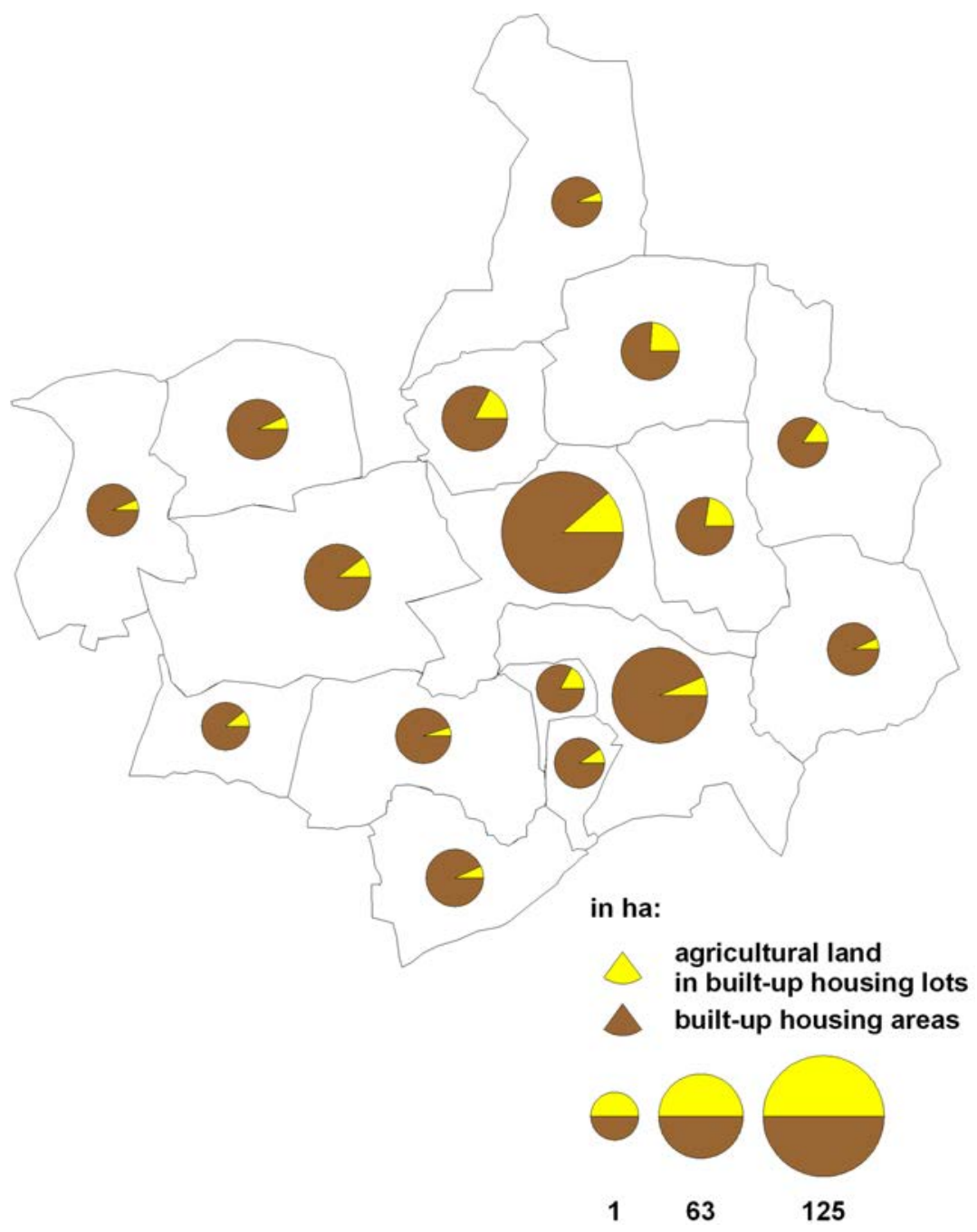

Fig. 6. Total housing area (all housing areas in the commune) and farmland on built-up housing lots in Rokietnica commune, 2014.

Source: own compilation on the basis of data from the Poviat Centre of Geodetic and Cartographic Documentation in Poznań. 
housing lots is nearly 42 ha, as already mentioned. This means that the discrepancy between the data shown in the real-estate cadastre and the actual use of land is $12 \%$ in the case of the builtup housing area, because the actual area of builtup housing lots is 345 ha, of which 42 ha are agricultural land. In some districts this discrepancy is especially high. If agricultural land on built-up housing lots was included in the built-up housing area, the actual figure of the latter would be $31 \%$ higher in Rostworowo, 29\% higher in Bytkowo, and $21 \%$ higher in the Krzyszkowo and Starzyny districts (Fig. 6).

\section{Summing up}

The conducted research has corroborated that the practice of partial exclusions of farmland from agricultural production, allowed by the Farmland and Woodland Protection Act of 3 February 1995, is widespread in areas undergoing suburbanisation. At the close of 2014, nearly 7\% (927) of all geodetic lots in Rokietnica commune (both built-up and building-free) were built-up housing lots with fragments of agricultural land. Almost in all cases this was arable land. It was also established that built-up housing lots with agricultural land could be found in all the geodetic districts of the commune, but their greatest number was in its most urbanised districts: Rokietnica (322), Kiekrz (126) and Krzyszkowo (119). Almost a half $(49.4 \%)$ of the total area of those lots, 42 ha, was still agricultural land in the real-estate cadastre and subject to taxation not by the real-estate tax, but by the much lower agricultural tax. Because of this difference in the two taxes, the annual receipts of the commune budget are 186,601 zlotys (43,395 euro) lower. In some districts the losses deriving from this difference are especially high; in Rokietnica, Krzyszkowo and Kiekrz they amount to 63,424 zlotys $(14,750$ euro), 23,173 zlotys (5,389 euro) and 23,003 zlotys (5,349 euro) respectively. It also turned out that more than $50 \%$ of farmland on those lots ( $21.8 \mathrm{ha}$ ) was arable land of the good land-capability class III, which is high in the conditions of the Poznan agglomeration. This situation is understandable because many of those lots with soils of class III can be found in the central part of the town of Rokietnica, i.e. in an area most predestined to be urbanised. Hence its convergence from farmland to housing and service functions was unavoidable and fully justified. Still, at least some farmland in the commune with soils of the high class III could, and should, remain in agricultural use. This concerns areas distant from the town's centre, where the scattering of buildings makes the housing function unfavourable, if only because of the high cost of providing them with infrastructure. The research conducted not only corroborates the findings of earlier studies highlighting significant losses of arable land, also that of good quality, taking place as a result of urban sprawl, but it also means that in the Polish conditions actual losses are much higher than would follow from records in the real-estate cadastre. It can also be stated that the Polish legal rules not only fail to adequately protect farmland situated within metropolitan areas, but even favour its excessive loss.

\section{References}

Bański J., 2005. Przestrzenny wymiar współczesnych procesów na wsi (Spatial dimension of contemporary processes in the countryside). Studia Obszarów Wiejskich 9, IGiPZ PAN, PTG, Warszawa.

Bielecka E., Całka B., 2012. Analiza procesu wyłączeń gruntów z produkcji rolnej i leśnej na terenach wiejskich (Analysis of the process of exclusion of land from agricultural and woodland production in rural areas). Infrastruktura i Ekologia Terenów Wiejskich 2: 163-173.

Borszowski P., 2011. Ustawa o podatkach i optatach lokalnych. Komentarz (The Tax and Local Payments Act. A commentary). LexisNexis Polska.

Brzezicki T., Flisz I., 2013. Należność i opłata roczna za wyłączenie gruntów z produkcji rolnej lub leśnej - wymiar i egzekucja (Dues and annual charges for the exclusion of land from agricultural or woodland production: amount and execution). Casus Krajowa Reprezentacja Samorządowych Kolegiów Odwoławczych 70: 39-42.

Etel L., Presnarowicz S., Dudar G., 2008. Podatki i opłaty lokalne. Podatek rolny. Podatek leśny. Komentarz (Local taxes and payments. Agricultural tax. Forest tax. A commentary). Wolters Kluwer Polska.

FAO, ITPS, 2015. Status of the World's Soil Resources (SWSR) - Main Report. Food and Agriculture Organization of the United Nations and Intergovernmental Technical Panel on Soils, Rome, Italy 650.

Gardi C., Panagos P., Van Liedekerke M., Bosco C., De Brogniez D., 2015. Land take and food security: assessment of land take on the agricultural production in Europe. Journal of Environmental Planning and Management 58: 898-912.

Gaudemet P.M., Molinier J., 2000. Finanse publiczne (Public finance). Polskie Wydawnictwo Ekonomiczne, Warszawa.

Heimlich R., Anderson W., 2001. Development at the urban fringe and beyond: impacts on agriculture and rural 
land. Economic Research Service, U.S. Department of Agriculture, Agricultural Economic Report No. 803.

Kacprzak E., Maćkiewicz B., 2011. Wyłączenia użytków rolnych $\mathrm{z}$ produkcji rolniczej $\mathrm{w}$ powiecie poznańskim $\mathrm{w}$ latach 2000-2009 (Exclusion of farmland from agricultural production in Poznań poviat in the years 2000-2009). In: Kacprzak E., Maćkiewicz B. (eds), Gospodarka rolna w aglomeracji poznańskiej. Bogucki Wydawnictwo Naukowe, Poznań: 61-70.

Kacprzak E., Maćkiewicz B., 2013. Farmland conversion and changes in the land-use pattern in the Poznań agglomeration in the years 2000-2009. In: Kołodziejczak A. (ed.), Quaestiones Geographicae 32(4): 91-102.

Kacprzak E., Staszewska S., 2008. Rozwój obszarów mieszkaniowych w strefie podmiejskiej miasta Poznania (Development of housing areas in the suburban zone of Poznan city). In: Jezierska-Thöle A., Kozłowski L. (eds), Gospodarka przestrzenna w strefie kontinuum miejsko-wiejskiego w Polsce. Wydawnictwo Naukowe Uniwersytetu Mikołaja Kopernika, Toruń: 127-144.

Kacprzak E., Staszewska S., 2009. Zmiany struktury funkcjonalno-przestrzennej jednostek osadniczych strefy podmiejskiej dużych ośrodków miejskich (na przykładzie strefy podmiejskiej miasta Poznania) (Changes in the functional-spatial structure of settlement units in the suburban zones of large urban centres: An example of the suburban zone of Poznań city). In: Marszał T. (ed.), Struktura funkcjonalna matych miast. Wydawnictwo Uniwersytetu Łódzkiego, Łódź: 51-68.

Kacprzak E., Staszewska S., 2011. Wpływ suburbanizacji na wiejskie struktury osadnicze (Effect of suburbanisation on rural settlement structures). Studia Miejskie 3: 99-112.

Kajdanek K., 2012. Suburbanizacja po polsku (Suburbanisation Polish style). Zakład Wydawniczy NOMOS, Kraków.

Kołodziejczak A., Kacprzak E., 2016. Funkcje rolnicze (Agricultural functions). In: Kaczmarek T., Mikuła Ł. (eds), Koncepcja kierunków rozwoju przestrzennego metropolii Poznań. Centrum Badań Metropolitalnych UAM, Poznań: 75-83.

Kwartnik-Pruc A., Bydłosz J., Parzych P., 2011. Analiza procesu przeznaczania gruntów rolnych i leśnych na cele inwestycyjne (Analysis of designating agricultural and woodland areas for investment purposes). Studia $i$ Materiaty Towarzystwa Naukowego Nieruchomości 19 (4): 169-178.

Levia J.D.F., Page D.R., 2000. The use of cluster analysis in distinguishing farmland prone to residential development: a case study of Sterling, Massachusetts. Environmental Management 25: 541-548.

Maćkiewicz B., 2007. Rynek nieruchomości niezabudowanych w Poznaniu i powiecie poznańskim w latach 1995-2000 (Market of building-free real-estate in Poznań and Poznań poviat in the years 1995-2000). Bogucki Wydawnictwo Naukowe, Poznań.

Maćkiewicz B., 2011. Sprzedaż gruntów z Zasobu Własności Rolnej Skarbu Państwa w Poznaniu i powiecie poznańskim w latach 2000-2009 (Sale of land from the Agricultural Property Stock of the State Treasury in Poznań and Poznań poviat in the years 2000-2009). In: Kacprzak E., Kołodziejczak A. (eds), Regionalne zróżnicowanie rozwoju społeczno-gospodarczego na obszarach wiejskich. Bogucki Wydawnictwo Naukowe, Poznań: 91-103.

Maćkiewicz B., 2015 Przekształcenia gruntów rolnych sprzedanych z Zasobu Własności Rolnej Skarbu Państwa (Transformation of farmland sold from the Agricultural
Property Stock of the State Treasury). Studia Obszarów Wiejskich 37: 169-180.

Maćkiewicz B., 2016 Gospodarka gruntami (Land management). In: Kaczmarek T., Mikuła Ł. (eds), Koncepcja kierunków rozwoju przestrzennego metropolii Poznań. Centrum Badań Metropolitalnych UAM, Poznań: 171-179.

Maćkiewicz B., Kacprzak E., 2015. Policies of farmland use in the agglomeration of Poznań. Studia Regionalia 41-42: 115-128.

Maćkiewicz B., Motek P., 2014. Wyłączenia gruntów rolnych z produkcji rolnej a dochody gmin z podatku od nieruchomości (Exclusion of farmland from agricultural production and the receipts of communes from the real-estate tax). Rozwój Regionalny i Polityka Regionalna 28, Bogucki Wydawnictwo Naukowe, Poznań: 69-77.

Malinowska-Misiąg E., Misiąg W., 2014. Finanse publiczne w Polsce (Public finance in Poland). LexisNexis, Warszawa.

Mikuła Ł. (ed.), 2016. Integracja planowania przestrzennego w Metropolii Poznan - problemy, metody, osiagnięcia (Integration of physical planning in the Poznań metropolis: problems, methods, achievements). Bogucki Wydawnictwo Naukowe, Poznań.

Miszczuk M., 2009. System podatków i opłat samorządowych w Polsce (System of taxes and local-government payments in Poland). Wydawnictwo C.H. Beck, Warszawa.

Martellozzo F., Ramankutty N., Hall R.J., Price D.T., Purdy B., Friedl M.A., 2014. Urbanization and the loss of prime farmland: a case study in the Calgary - Edmonton Corridor of Alberta. Regional Environmental Change 15: 881-893.

Lisowski A., Grochowski M., 2007. Procesy suburbanizacji. Uwarunkowania, formy $i$ konsekwencje (Suburbanisation processes: determinants, forms and consequences). Ministerstwo Rozwoju Regionalnego, Warszawa.

Owsiak S., 2016. Finanse publiczne. Teoria i praktyka (Public finance. Theory and practice). Wydawnictwo Naukowe PWN, Warszawa.

Polimeni J., 2005. Simulating agricultural conversion to residential use in the Hudson River Valley: scenario analyses and case studies. Agriculture and Human Values 22: 377-393.

Pribadi D.O., Pauleit S., 2015. The dynamics of peri-urban agriculture during rapid urbanization of Jabodetabek metropolitan area. Land Use Policy 48: 13-24.

Salvati L., 2013. Monitoring high-quality soil consumption driven by urban pressure in a growing city (Rome, Italy). Cities 31: 349-356.

Satterthwaite D., McGranahan G., Tacoli C., 2010. Urbanization and its implications for food and farming. Philosophical Transactions of the Royal Society B Biological Sciences 365: 2809-2820.

Scalenghe R., Marsan F.A., 2009. The anthropogenic sealing of soils in urban areas. Landscape and Urban Planning 90: $1-10$.

Scong K.L., Steinnes M., 2016. How do centrality, population growth and urban sprawl impact farmland conversion in Norway? Land Use Policy 59: 185-196.

Sygut E., 2014. Podatki i opłaty lokalne jako źródła dochodów gmin na przykładzie województwa śląskiego (Taxes and local payments as a source of income for communes: an example of Silesian voivodeship). In: Sokołowski J., Sosnowski M. (eds), Finanse publiczne. Wydawnictwo Uniwersytetu Ekonomicznego we Wrocławiu, Wrocław: 289-298.

Śleszyński P., 2016. Konferencja „Społeczne, gospodarcze i przestrzenne wyzwania dla polityki rozwoju Warszawy 
i jej obszaru metropolitalnego" (Conference on "Social, economic and spatial challenges for the development policy of Warsaw and its metropolitan area"). Przeglad Geograficzny 88(2): 287-290.

Tóth G., 2012. Impact of land-take on the land resource base for crop production in the European Union. Science of the Total Environment 435-436: 202-214.
Wójcik M., 2008. Przemiany społeczno-gospodarcze wsi aglomeracji tódzkiej w okresie transformacji ustrojowej (Socio-economic changes in the countryside of the Łódź agglomeration in the period of the systemic transformation). Wydawnictwo Uniwersytetu Łódzkiego, Łódź. 